\title{
THE EFFECTS OF INTER-CROP CULTIVATION BETWEEN ROWS OF CITRUS CROP ON SPREADING OF Guignardia citricarpa ASCOSPORES AND IN THE CITRUS BLACK SPOT OCCURRENCE ${ }^{1}$

\author{
JOSÉ ANTONIO MIRANDA BELLOTTE ${ }^{2}$, KATIA CRISTINA KUPPER ${ }^{3}$, \\ DAVI RINALDO ${ }^{4}$, ANDRESSA DE SOUZA $^{5}$, ANTONIO DE GOES $^{6}$
}

\begin{abstract}
This study highlighted the effect of planting coast-cross grass and forage peanut cv. Amarilis between rows of Natal oranges on spreading of Guignardia citricarpa ascospores and consequent citrus black spot control. Treatments evaluated were: 1- conventional cultivation, free of fungicides; 2- conventional cultivation, using protective fungicides; 3 - inter-crop cultivation of coast-cross grass between rows of citrus crops and; 4- inter-cropping cultivation of forage peanut between the rows of citrus crops. Quest Volumetric Spore System ${ }^{\mathrm{TM}}$ traps were set in order to determine the number of ascospores released. A total of 33 inspections were conducted weekly, from the end of August until early September the following year. A diagrammatic scale was used to determine the severity of the disease as well as the percentage of fruits having a commercial standard. The coast-cross grass was more effective in reducing the number of ascospores produced, whose average statistics were lower than in the conventional treatments, free-fungicides. The intercrop and conventional cultivation method coupled with fungicide treatment was more effective in reducing the severity of citrus black spot symptoms, and differs statistically from the fungicide-free control method. These methods also resulted in a higher percentage of fruits of a commercial standard, ranging from the $89 \%$ through the $91 \%$ percentile, and the cultivation, free of fungicides, fell within the $73 \%$.
\end{abstract}

Index terms: Citrus sinensis; Cultural control; Phyllosticta citricarpa; Arachys pintoi; Cynodon dactylon

\section{EFEITO DE CULTIVOS INTERCALARES NAS ENTRELINHAS DOS CITROS NA LIBERAÇÃO DE ASCÓSPOROS DE Guignardia citricarpa E NA OCORRÊNCIA DA MANCHA PRETA DOS CITROS}

RESUMO - No presente, foi avaliada a influência do amendoim-forrageiro cv. Amarillis e da gramínea coastcross nas entrelinhas de plantas de laranjeira 'Natal' quanto à produção e liberação de ascósporos de G. citricarpa, e consequente controle da mancha-preta dos frutos cítricos. Os tratamentos avaliados foram: 1- cultivo convencional, sem utilização de fungicidas; 2- cultivo convencional, com utilização de fungicidas; 3-gramínea coastcross, e 4-amendoim forrageiro entre as linhas das plantas. O monitoramento de ascósporos deu-se mediante armadilhas caça-esporos do tipo Quest Volumetric Spore System ${ }^{\mathrm{TM}}$. Um total de 33 inspeções foi realizado semanalmente, a partir do final de agosto até início de setembro do ano seguinte. A quantificação da doença deu-se mediante utilização de escala diagramática de notas, sendo também determinada a porcentagem de frutos com padrão comercial. A gramínea coastcross foi o melhor tratamento em reduzir o número de ascósporos liberados, diferindo, estatisticamente, do convencional, porém não dos demais tratamentos. Cultivo intercalar e cultivo convencional associado com aplicações de fungicida foram os mais eficientes quanto à redução da severidade de sintomas da mancha-preta, diferindo do tratamento-testemunha, sem emprego de fungicida. Esses tratamentos foram os que também proporcionaram a maior porcentagem de frutos com padrão comercial, sendo de $89 \%$ a $91 \%$, enquanto no cultivo convencional, sem uso de fungicidas, foi de $73 \%$.

Termos para indexação: Citrus sinensis, Controle Cultural, Phyllosticta citricarpa, Arachys pintoi, Cynodon dactylon.

\footnotetext{
${ }^{1}$ (Trabalho 142-12). Recebido em: 10-04-2012. Aceito para publicação em: 10-03-2013.

${ }^{2}$ Agronomist. Louis Dreyfus Commodities Agroindustrial Ltda, Estrada de Botucatu-Itatinga, km 12, São Paulo. jose.bellotte@ldcom.com ${ }^{3}$ Dr. and Scientific Researcher. Centro APTA Citros Sylvio Moreira, Instituto Agronômico, Av. Anhanguera, km 158, CEP 13490-970, Cordeirópolis-SP. E-mail: katia@centrodecitricultura.br

${ }^{4}$ Agronomist. Universidade Estadual Paulista, FCAV/UNESP, CEP 14884-900, Jaboticabal-SP. E-mail: d.rinaldo@bol.com

${ }^{5}$ Agronomist. Universidade Estadual Paulista, FCAV/UNESP, CEP 14884-900, Jaboticabal-SP. E-mail: andressa unesp@yahoo.com.br

${ }^{6}$ Dr. in Phytopathology. Universidade Estadual Paulista, FCAV/UNESP, CEP 14884-900, Jaboticabal-SP. E-mail address: adggoes@ yahoo.com.br
} 


\section{INTRODUCTION}

Despite high economic significance and importance of the citrus industry in Brazil, especially in São Paulo, the citrus groves appear to be vulnerable to various biotic agents, including fungi. Part of this vulnerability to biotic agents is due to perennity of plants, lack of spatial and temporal discontinuity, and the existence of environments favorable to these agents for long period throughout the year (SOUSA;GOES, 2010).

Citrus black spot (CBS) is among the most important one of the more common diseases in sweet orange trees (Citrus sinensis (L.) Osbeck) and is caused by the fungus Guignardia citricarpa Kiely [Anamorphic form: Phyllosticta citricarpa (McAlp.) Van der Aa]. It infects leaves, branches and mainly fruits which devalues their quality. Once the disease is considered an A1 quarantine disease by the European Union, who is the main importer, it seriously limits the possibility to export in nature fruits. Additionally, when plants are highly severely infected, the fruit can fall prematurely, decreasing plant productivity. In areas where there are high levels of inoculum, multiple applications of fungicide are required. This additional expense raises production costs considerably (SCALLOPPI at el., 2012).

Two sources of inoculum are responsible for CBS: conidia and ascospores. Conidia forms on lesioned leaves, fruit and dry branches. When it rains or is misty during the night it can infect susceptible organs, and cause new infections. Ascospores on the other hand, form exclusively on fallen citrus leaves. When mature these structures are ejected into the atmosphere and can infect the different organs of plant (KOTZÉ, 1981).

Disease is controlled primarily by using fungicides (GOES, 2002). However, this alternative must be complemented by additional measures conducive to intensifying control and minimizing harmful side effects to the environment. BELLOTTE et al. (2009) demonstrated that pathogen could be controlled more effectively by putting leaf decomposers and nitrogen fertilizers on fallen citrus leaves.

Although both sources of inoculum, i.e. ascospores and conidia, are fundamental to the spread of disease, ascospores, given their dynamics of reproduction and ease of dissemination, are responsible for the dispersal of pathogen at varying distances, as well as generating disease between plants. In this context, considering that the only substrate for its formation are fallen leaves (KOTZÉ,
1981), therefore, covering the orchard with mulch can prevent its formation, growth and spread, consequently scale down the disease severity. Similar to mulching, cultivating plants, having decumbent growing habits which satisfactorily breed between rows of citrus crops and under canopies of citrus plants in all rusticity can have an adverse effect on the pathogen cycle, since they could accelerate decomposition of fallen leaves and consequently hinder the formation and spread of G. citricarpa's reproductive spores. Furthermore, even though conditions for the production of ascospores remain, such coverage could also act as a physical barrier making their release more difficult.

The coast-cross grass is a perennial plant, rhizomatous and stoloniferous, whose roots intertwine easily. It grows abundantly leaving no areas uncovered, and forms a dense, soft surface, which may have the desired effect in reducing or suppressing the formation of G. citricarpa's ascospores. On the other hand, the forage peanut, owing to its decumbent growing habits, has the ability to cling the stems and maintains itself in the soil through its seeds (JONES, 1993). It also has the potential to be an alternative coverage to fallen citrus leaves under the crowns and can, therefore, assist in reducing the generation and spread of ascospores.

Taking the above into consideration, the objective of this research is to examine the effects of cultivating cost-cross grass and forage peanuts between rows of citrus crop on spread of ascospores of G. citricarpa and, the subsequent control of citrus black spot on fruits.

\section{MATERIALS AND METHODS}

Experiment and treatment site - The experiment was conducted in a 7-year-old 'Natal' orange tree orchard (Citrus sinensis (L). Osbeck), and grafted onto a Poncirus trifoliate Raf., on a private property in Rio Claro/SP (latitude $22^{\circ} 25^{\prime}$ $\mathrm{S}$ and longitude $47^{\circ} 18^{\prime} \mathrm{W}$ ). The soil is classified as alluvial hydromorphic and organic, relative to the Rio Claro and Corumbataí lithology formation. Climatic conditions in the Rio Claro region are tropical category (Cwa according to Köeppen's classification), with a rainy summer (October to March) and dry winter (April to September). The average annual precipitation is $1,482 \mathrm{~mm}$ and the average temperature all year round is $20^{\circ} \mathrm{C}$, according to UNESP's Department of Environmental Planning and Analysis Weather Station in Rio Claro (PRATA et al., 2007). The experiment consisted of four methods: (1) fungicide-free conventional cultivation combined 
with mowing (i) sub-crown mowing, followed by (ii) mowing between rows of crops, with mowed weeds positioned precisely under the tree crowns and; (2) conventional cultivation, using fungicides combined with mowing as previously described; (3) coast cross grass (Cynodon dactylon L.); (4) forage peanut (Arachys pintoi Krap et Greg.) cv. Amarillo. Each experiment consisted of an area of plants vegetatively uniform, standing erect, having a flat surface and uniform across the experimental area. An area consisting of 12 rows of plants, occupying the physical space of $84 \mathrm{~m} \times 180 \mathrm{~m}$, totaling $15,120 \mathrm{~m}^{2}$ was allotted to each treatment. There were 720 plants, in each area measuring $6 \mathrm{~m} \times 3,5 \mathrm{~m}$ which was the spacing among plants.

Inter-crop cultivation between rows of crops - Coast-cross grass and forage peanut seedlings were planted in February 2004. The coast-cross grass was planted manually, from tussocks which were obtained from the farm. These seedlings were distributed evenly between the rows of crops, at a distance of $1 \mathrm{~m}$ from the canopy of the orange trees. A Marchesan ${ }^{\circledR}$ motorized vacuum seeder, model $\mathrm{PST}^{3}$ was used to plant the forage peanut seedlings, in four rows, at a rate of $15 \mathrm{~kg} / \mathrm{ha}$. The seeding density was set at eight seeds per meter. The spacing agreed upon was $0.5 \mathrm{~m}$ between rows of plants, maintaining a distance of $1 \mathrm{~m}$ from the orange trees. Brachiaria decumbens Stapf was predominant in the conventional cultivation between rows of plants.

As for weed control in the rows of coast cross grass and peanut, an amount of $3 \mathrm{~L}$ p.c. /ha of MSMA ${ }^{\circledR}$ herbicide was applied. During the first three months of the experiment, herbicide glyphosate $(1 \mathrm{~L} / \mathrm{ha})$ was sprayed in the orchard, with flow rate of $150 \mathrm{~L} / \mathrm{ha}$. The same treatment was also applied in the corresponding conventionally cultivated areas but only in the soil basins and further complemented by mowing between rows of crops.

Conducting the experiment - Two cupric fungicide (copper hydroxide, Kocide $\mathrm{WDG}^{\mathrm{TM}}$ at $0,125 \%$ ) applications were made in all areas, with the exception of that corresponding to conventional cultivation, which was free of fungicide. The first cupric fungicide was sprayed on 10/19/04 at a stage when $3 / 4$ of the petals had fallen, and the second on 11/22/04. The Jacto ${ }^{\circ}$ Arbus 2000 sprayer complete with a unilateral deflector was used; a JP-150 hydraulic pump with a capacity of $150 \mathrm{~L} / \mathrm{min}$., 540 rpm power take-off (PTO) and a fan diameter of $850 \mathrm{~mm}$. The sprayer's average speed was $4 \mathrm{~km} / \mathrm{h}$, conforming to Rabbinge et al. (1989). Mowing between rows of crops was done at approximately 30-day intervals, while the remaining cultural care was done in accordance with the standards adopted by the property owners.

Installing spore traps and disc readings - Quest Volumetric Spore System ${ }^{\mathrm{TM}}$ traps were installed to determine the number of ascospores released. Their acrylic discs had to be monitored weekly, because these structures, when present, would stick to the surface. Such discs were sprayed with petroleum jelly before being placed in the trap so that the fungus's structures would adhere better to their surface. The spore traps were placed in the center of the plots 1, 3 and 4. It was deemed unnecessary to install a spore trap in the case of treatment 2, due to its similarity to treatment 1 . At the end of the seventh day, the discs were collected and sent to the Plant Pathology Laboratory in the Phytosanitary Department of UNESP, Jaboticabal, where readings were taken, following the methodology outlined by Reis et al. (2006). The traps were installed in the second half of August and the readings were taken at the beginning of the first week of September. As for the characteristics of the fungus's reproductive spores and standardized readings, the descriptions prepared by Sutton \& Waterson (1996) were used as a guideline. When estimating the number of ascospores collected, precipitation data were also monitored by Ville de Paris ${ }^{\mathrm{TM}}$ pluviometer which had been installed in all the experimental areas.

\section{Evaluating and analyzing results -} The quantity of ascospores was analyzed taking into account the effects that green coverage and conventional culture have on the reproduction and/or spread of ascospores collected in the spore traps. The data obtained were correlated with the pluviometric precipitation data and also with the levels of disease encountered. A total of 33 evaluations were performed on the number of ascospores detected, corresponding thus to 33 weeks of monitoring. A comparative analysis of such data was made alongside the average number of ascospores detected each week. Quantifying the disease incidence levels and severity of symptoms on fruits was effected by applying a diagrammatic scale ranging from zero (no symptoms) to six (maximum severity), in conformity with Fagan \& Goes (1999). As for assessing the severity of the symptoms, ten plants from the middle rows in the centre of each experimental block were marked, from which 100 fruits were picked from the entire perimeter of the plant. Thereafter the disease index (DI) was determined by using the McKinney 
index formula (1923) as indicated:

$$
D I=\frac{\sum_{k=1}^{K} F_{k} x_{k}}{n x_{k}}
$$

where, $F_{k}=$ number of fruits marginally infected $x_{k}, k=0,1, \ldots, k$, in the plot; $n$ equals the number of fruits examined; $x_{k}$ equals the highest number from the adopted scale. To ascertain the average normality and homogeneity variance, the infection intensity index (I) was recorded. It was expressed by $\mathrm{I}=\operatorname{sen}^{2} \mathrm{w}$, whose angular transformation $\mathrm{w}=\operatorname{arcsen} \sqrt{\mathrm{I}}$ was determined by statistical analysis procedures as proposed by Czermainski (1999). The remaining procedures adhered to were similar to those applied by Bellotte et al. (2009). This study also took into account the number of fruits having a commercial value. Only fruits presenting a severity of $\leq 3.0$ ( $\leq 5.6$ lesioned area) were considered to be of an acceptable commercial standard, according to the scale proposed by (FAGAN; GOES, 1999). Fruit with minor symptoms, showing signs of depreciation, are not restricted on the internal market.

Chemical analysis of citrus leaves - A chemical analysis of the foliage tissue was conducted to determine the effects varying types of vegetal coverage had on the nutritional value of the citrus plants. In order to do this, in February of the year after planting, the third and fourth leaves were collected from the branches bearing fruit. Twenty-five plants were examined in all, of which four leaves were collected per quadrant at medium crown height (GRUPO PAULISTA, 1988; VITTI, 1988). Chemical analyses of these leaves were carried out at the Soil and Fertilizer Department of UNESP, in Jaboticabal. To interpret the results was taken as reference the rules established for the cultivation of citrus in São Paulo, according to Grupo Paulista methodology (1994).

\section{RESULTS AND DISCUSSION}

The largest numbers of ascospores collected were in spore traps installed in the corresponding control treatment area, consisting of the fungicide free conventional culture. The average number of ascospores detected differed significantly from that in the corresponding treatment of inter-crop cultivation with coast-cross grass, where the lowest number of ascospores was found (Table 1). In the corresponding treatment of forage peanut between rows of crops, an intermediate number of ascospores was obtained, which did not differ statistically from the other treatments.

In comparison with other treatments, the lowest number of ascospores detected in the grassy areas is apparently attributable to its vegetative development potential. This grass, which normally produces a great deal of vegetal mass, probably provided the right coverage, forming a barrier preventing the formation and spread of the ascospores. Furthermore, it is likely, given that levels of humidity are constantly high, decomposition of citrus leaves already on the ground could be further accelerated and eventually covered by the plant mass.

When compared with the area cultivated with coast-cross grass a greater number of ascospores were found in the spore traps set in the forage peanut area. This difference could possibly be attributed to the slow development of the forage peanut in the first instance, which results in the low production of stolons fewer branches and leaves. This plant, besides showing slow signs of initial growth, developed poorly during the weeks prior to the assessments because of low rainfall. According to Correia \& Nogueira (2004), forage peanut plants suffer when subjected to low humidity, resulting in lower green mass production.

The amount of green mass formed by the plants cultivated between rows of crops, although it has not yet been visibly confirmed, however, was considerably higher in the coast-cross grass areas when compared with the area covered by the forage peanut. In literature, data suggest that coast-cross grass dry matter production can be up to $20 \mathrm{t} / \mathrm{ha}$ /year (CACERES et al., 1989), whereas forage peanut reaches $10 \mathrm{t} / \mathrm{ha} /$ year, per single culture.

In the treatment corresponding to the conventional culture, ascospores were detected in the spore traps in the first week of monitoring (Figure 1 ), whereas it began in the fourth and fifth weeks, respectively in the coast-cross grass and forage peanut areas (Figures 2 and 3 ).

Over time, it was found that during the 33 weeks of monitoring, ascospores were detected in 29 weeks in the area covered by conventional cultivation and 23 weeks in the forage peanut area, and only 14 weeks in the coast-cross grass areas. In relative terms these results indicate that there was evidence of ascospores in $88 \%$ of the areas cultivated conventionally, $70 \%$ in the forage peanut area, while in the coast cross grass areas it was only $42 \%$. However, the number of ascospores detected varied depending on the function of the areas assessed and demonstrated intermittent peaks of differing 
intensity.

The volume of rain during June, July and August, was 32, 02 and $01 \mathrm{~mm}$ respectively. The amount of rainfall during the 90 days prior to monitoring the ascospores was about $35 \mathrm{~mm}$. Therefore, considering that only $5 \mathrm{~mm}$ of rain is needed to enable the ascospores to mature and spread (KOTZÉ, 1981), it is assumed that the low number of ascospores found in the treatment area corresponding to conventional cultivation is due to the low volume of pluviometric precipitation. However, although the amount of vegetation in the remaining treatments areas covered by the forage peanut was smaller, it was enough to inhibit or reduce their reproduction. Subsequently, after the third week, and with the onset of the spring rains, $8 \mathrm{~mm}$, the ascospores began to spread intermittently, in all treatment areas, but more intensely in the corresponding areas undergoing conventional tillage.

The intermittent distribution ascospores results, among other things, from leaves decomposing at different levels under tree canopies caused by the soil's moisture which also varies at different levels, which, in turn affects the amount of leaves existing on its surface.

In this study it was found that ascospores were released during two specific periods of time, the first was between the 5 th and 12 th weeks of inspection, and the second, and more significant in terms of intensity, was between the $23 \mathrm{rd}$ and 27 th weeks.

These reactions tie in largely with periods of low rainfall, no rain at all, or intermittent showers. These aspects appear to be consistent with the biological needs of the fungus for the creation of reproductive spores, thus confirming the necessity of moistening and drying leaves alternately in the process of formation and release of reproductive spores, as observed by researchers (KIELY, 1949; 1963; McONIE, 1964; KOTZÉ, 1981). Such evidence appears to be more remarkable when one examines the records of the number of ascospores detected between the $23 \mathrm{rd}$ and 27 th weeks. It can be seen from Figure 1 that in the weeks prior to that a large number of ascospores were detected as a result of frequent and intense rainfall. One likely hypothesis is that the ascospores present in the layer of turbulence were removed from the atmosphere by water droplets. It is also likely that the leaves remained damp for an extended period of time, and decayed before the ascospores were formed which would somehow inhibit their release.

While using the Hirst spore trap, McOnie (1964; 1965) discovered that citrus fruits infections were significantly attributable to the abundance of ascospores. According to the author who reported on the situation in South Africa, the spread of ascospores peaked in November and December, which falls in line with the present study.

Research involving the analysis of the following influential factors: temperature, rainfall, leaf moisture, humidity relative to formation, the discharge and germination of ascospores, has been undertaken by many researchers, from different countries, taking the different pathosystems into account. In this context, the interaction with Malus-Ventura inaequalis has been examined more than any other. According to (MAcHARDY; GADOURY, 1986) and Stensvand et al. (1997), the low temperature attributed to a greater discharge of ascospores of $V$. inaequalis, ascospores while leaf dampness contributed significantly to the disease occurrence (HARTMAN et al., 1999). It was noted in the case of Anisograma anomala fungus, the agent causing spots on hazelnut leaves, that the majority of ascospores were released during the autumn rainfalls, extending throughout the spring (GOTTWALD; CAMERON, 1980; PINKERTON et al., 1998). As for Mycosphaerella capsellae, the agent responsible for white leaf spot in rape, the discharge of ascospores was verified by using a Burkard spore trap. It was confirmed that this discharge always occurred after foliage had been moist for long periods of time as a result of dew or rain (INMAN et al., 1999).

As for the Citrus-G. citricarpa pathosystem, rain is essential for the formation and discharge of the ascospores pathogen (McONIE, 1964; FOGLIATA et al., 2001). According to the data collated in the present study, it was noted that there were higher discharges of ascospores between the months of November and January, in conformity with the data published by Reis et al. (2006).

In relation to disease control, the most effective treatments were those consisting of fungicide usage, or which depended on the cultivation of forage peanut or coast-cross grass between the rows of citrus crops, where symptoms of the disease were far less severe (Table 2). When analyzing the percentage of fruits of a commercial standard, the same treatments were equally effective, ranging from $89 \%$ to $91 \%$ of fruits with low levels of severity, in comparison with the corresponding conventional cultivation, where fungicides were not used

Symptomatic fruits were found in all plants, indicating the presence of inoculum in all four experimental areas. The levels of severity observed and recorded in terms of disease index (McKINNEY, 1923) revealed that the cultivation with the use of fungicides was statistically different when compared 
with control treatment (Tukey, $P<0.05$ ). The disease index ranged from 0.38 , as in the conventional treatment, of after mowing and when using fungicide, up to 0.47 , in the control treatment, only with the use of mowing (Table 2). In terms of average statistics were obtained similar responses among the indices of McKinney (1923) and Czermainski (1999), indicating the normality and homogeneity of data of variance, since the residues of $\mathrm{W}$ and DI presented normal distribution and showed homogeneity of variance (data not shown).

When comparing the data concerning the number of ascospores detected (Table 1) with the disease index and percentage of commercial fruits (Table 2), was observed in the three variables examined, that the treatments with vegetal coverage (coast-cross grass and forage peanut) do not differ statistically from one another. In the same way the significantly higher number of ascospores in conventional cultivation, free of fungicides, also resulted in a higher rate of disease, indicating that they contributed more intensely to severity symptoms in the experimental areas fruits. It is concluded that the cultivation of coast-cross grass and forage peanut between the rows of citrus crops restricts the spread of ascospores, consequently reducing the severity levels of citrus black spot symptoms. Such effectiveness was comparable to that reached by means of conventional cultivation, in addition to fungicide applications functioning as an auxiliary measure to control citrus black spot. These equally promising results in restricting $G$. citricarpa by means of mulching with or without the use of fungicides were also reported by Kotze (J.M. Kotze, Pretoria, ZA, personally in April/1997) in South Africa. According to this researcher, after the use of mulching $72 \%$ of fruits were of a commercial standards, while $96 \%$ were when associated treated with fungicides. In the case of the control, however, only $59 \%$ of fruits were of a commercial standard.
In all plants examined, some symptomatic fruits were found indicating the presence and distribution of inoculum in all experimental plots. The levels of severity noted were registered according to type and scale (SPÓSITO et al., 2004) and established in terms of the disease index (McKINNEY, 1923), revealed that all treatment statistics differed from the final inspection (Tukey, $P<0.05)$.

The disease index ranged from 0.38 , as in the case of conventional manage plus protective fungicide treatment, and up to 0.47 in the control treatment (no fungicide) (Table 3). The comparison of means according to Czermainski (1999) showed the same results, with the control treatment differing from the others. The residues of $\mathrm{w}$ and DI showed normal distribution and variance homogeneity (data not presented).

Finally, it was concluded that neither the cultivation of coast-cross grass, nor the forage peanut, between the rows of crops affected the foliage nutrient content significantly. From an agricultural point of view this indicates that both crops are compatible with citrus plants, (Table 3). Apart from the treatments administered, it was noted that the majority of the nutrients found in the areas under examination, were adequate for cultivation. Among the macronutrients, only the phosphorus levels were considered to be on the low side but these factors were verified even in the control treatment. It is worth mentioning that fertilizing procedures adopted by the farm consisted of applications along the entire row cultivated as well as, under the tree crowns. If only the area under the tree crowns had been fertilized, and the coast-cross grass mowed frequently, this would then have resulted in an impoverished grassy area at the soil level and subsequent development loss. 


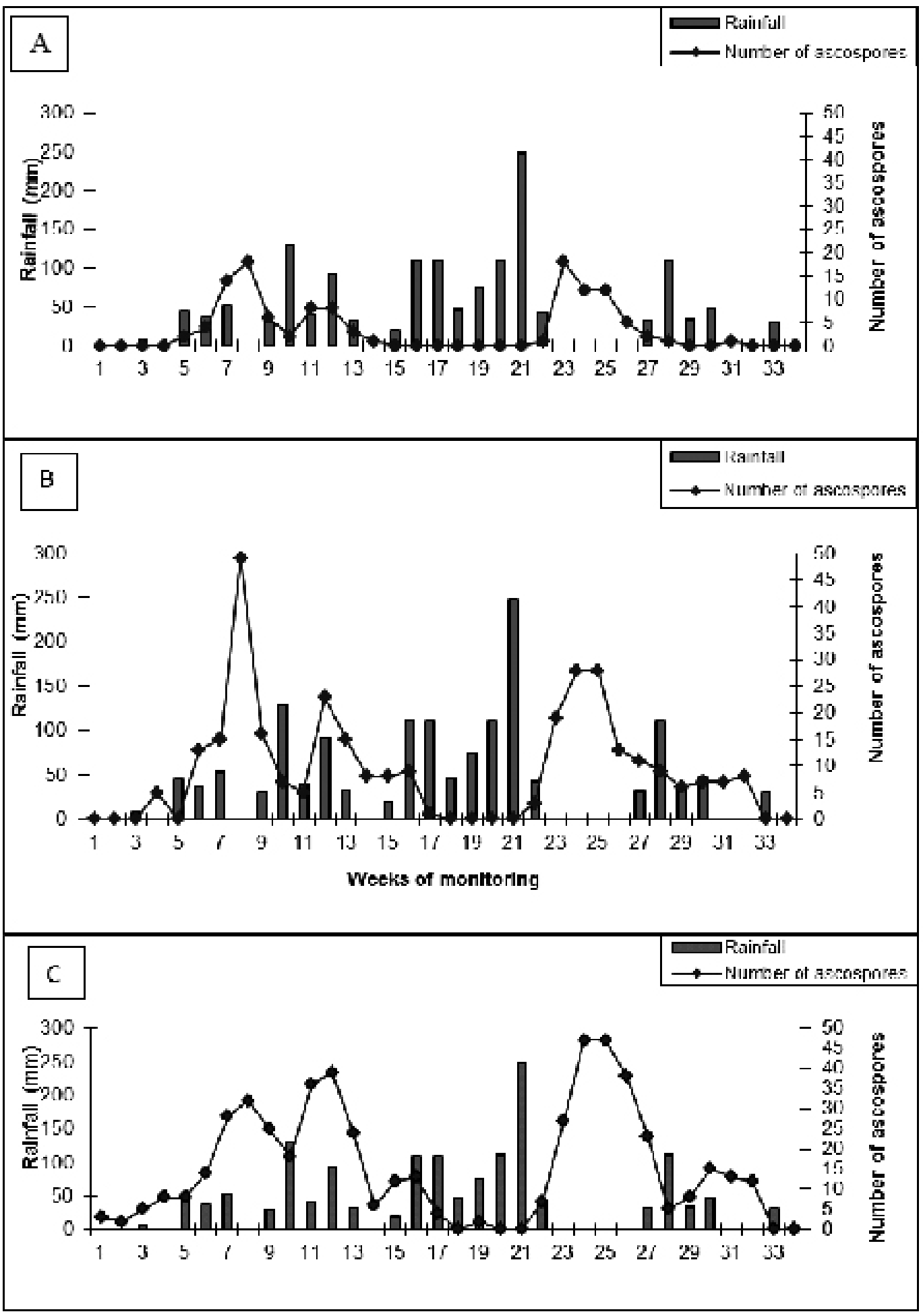

FIGURE 1 - Population fluctuation of Guignardia citricarpa ascospores and pluviometric precipitation from September 2004 to February 2005 in a 'Natal' orange tree orchard. A - In the forage peanut treatment. B - In the coast cross grass treatment. C - In the conventional management treatment. Rio Claro-SP. 
TABLE 1 - Weekly average of Guignardia citricarpa ascospores detected by the spore traps from September 2004 to April 2005 in a 'Natal' orange tree orchard. Rio Claro-SP.

\begin{tabular}{lc}
\hline Treatments & Number of ascospores/week \\
\hline Conventional cultivation (fungicide free) & $14.36 \mathrm{a}$ \\
Coast cross grass & $3.21 \mathrm{~b}^{*}$ \\
Forage peanut & $8.63 \mathrm{ab}$ \\
\hline
\end{tabular}

* Averages followed by the same letter do not differ among themselves (Tukey, $P<0.05$ ).

TABLE 2 - Disease index and \% of fruit with commercial standards observed in experiment with different management between the citrus plant crop lines, aiming for the formation of a coverage and disposition under the crowns to control of citrus black spot at a 'Natal' orange tree orchard. Rio Claro-SP.

\begin{tabular}{cccc}
\hline \multirow{2}{*}{ Treatments } & \multicolumn{2}{c}{ Disease Index $^{\mathrm{Y}}$} & $\begin{array}{c}\text { Commercial standard fruit } \\
(\%)\end{array}$ \\
\hline & McKinney's Index & Czermainsk's Index & \\
\hline Treat. 1 & $0.47 \mathrm{~b}^{\mathrm{Z}}$ & $43.784 \mathrm{~b}$ & $77.3 \mathrm{a}$ \\
Treat. 2 & $0.38 \mathrm{a}$ & $38.976 \mathrm{a}$ & $89.4 \mathrm{~b}$ \\
Treat. 3 & $0.41 \mathrm{ab}$ & $40.681 \mathrm{ab}$ & $91.1 \mathrm{~b}$ \\
Treat. 4 & $0.42 \mathrm{ab}$ & $41.405 \mathrm{ab}$ & $91.0 \mathrm{~b}$ \\
\hline
\end{tabular}

x Treat. 1- Conventional cultivation, fungicide free Treat. 2- Conventional cultivation with the use of fungicides; Treat. 3-Coast cross grass; Treat. 4- Forage peanut.

${ }^{Y}$ Disease Index: McKinney (1923) and Czermainski (1999).

${ }^{\mathrm{z}}$ Means followed by the same letter are not significantly different (Fisher, $P<0.05$ ).

TABLE 3 - Chemical analysis results from the 'Natal' orange leaves collected in the experimental area with different management between the citrus plant crop lines, aiming for the formation of a dead coverage and disposition under the crowns to control Guignardia citricarpa, the causal agent of citrus black spot. Rio Claro- SP.

\begin{tabular}{|c|c|c|c|c|c|c|c|c|c|c|c|}
\hline \multirow{2}{*}{ Treatment } & $\mathbf{N}$ & $\mathbf{P}$ & $\mathbf{K}$ & $\mathrm{Ca}$ & Mg & $\mathbf{S}$ & B & $\mathrm{Cu}$ & $\mathrm{Fe}$ & Mn & Zn \\
\hline & \multicolumn{6}{|c|}{$g / k g$} & \multicolumn{5}{|c|}{$m g / k g$} \\
\hline Control & 24.5 & 1 & 9 & 37.8 & 3.9 & 2.6 & 153 & 27 & 152 & 79 & 88 \\
\hline Forage Peanut & 24.5 & 1 & 10.3 & 31.2 & 3.4 & 2.7 & 112 & 22 & 117 & 58 & 58 \\
\hline Coast cross & 24 & 1.1 & 10.2 & 35.3 & 3.4 & 2.8 & 148 & 30 & 180 & 82 & 88 \\
\hline
\end{tabular}

\section{CONCLUSIONS}

1-Neither the cultivation of coast-cross grass, nor the forage peanut, between the rows of crops affected the foliage nutrient content.

2-Both crops are compatible with citrus plants;

3-The cultivation of the forage peanut or coast-cross grass between the rows of citrus crops reduces the ascospores spreading and increases the percentage of fruits with a commercial standard;

4-The fungicide treatment was efficient to citrus black control.

\section{ACKNOWLEDGEMENTS}

The authors would like to thank FAPESP Fundação de Amparo à Pesquisa do Estado de São Paulo - Fapesp, for their financial support (Number 01/10993-0); the Fazenda São José for their support and collaboration and Prof. Dr. Antonio Sérgio Ferraudo, for his help with the statistical analysis.

\section{REFERENCES}

BELLOTE, J. A. M; KUPPER, K. C.; RINALDO, D.; SOUZA, A. de; PEREIRA, F.D.; GOES, A. de Acceleration of the decomposition of Sicilian lemon leaves as an auxiliary measure in the control of citrus black spot. Tropical Plant Pathology, Lavras, v. 34, n.2, p. 71-76, 2009. 
CÁCERES, O.; SANTANA, H.; DELGADO, R. Influencia de la fertilización nitrogenada sobre el valor nutritivo y rendimiento de nutrientes. Pastos y Forrajes, Turrialba, v. 12, n. 2, p.189-195, 1989.

CORREIA, K.G.; NOGUEIRA, R.J.M.C. Avaliação do crescimento do amendoim (Arachis hypogea L.) submetido a déficit hídrico. Revista de Biologia e Ciência da Terra, Campina Grande, v. 4, n.2, p. 1-7, 2004.

CZERMAINSKI, A.B.C. Generalização de um índice de intensidade de infecção em experimentos de avaliação de doenças em plantas. Pesquisa Agropecuária Brasileira, Brasília, v.34, n.9, p. 1545-1555, 1999.

FAGAN, C.; GOES, A. de. Efeito da severidade da mancha-preta dos frutos cítricos causada por Guignardia citricarpa na queda de frutos de laranja 'Natal'. Fitopatologia Brasileira, Brasília, v.24, p.282s, 1999.

FOGLIATA, G.M.; PLOPER, L.D.; CANTON, N. Dinâmica de liberación de ascosporas de Guignardia citricarpa em Tucumán, Argentina. Fitopatologia Brasileira, Brasília, v. 26, p.469, 2001.

GOES, A. Efeito da combinação de fungicidas sistêmicos e protetores no controle da mancha preta dos frutos cítricos causada por Guignardia citricarpa. Summa Phytopathologica, Botucatu, v. 28, n. 1, p. 9-13, 2002.

GOTTWALD, T.R.; CAMERON, H.R. Infection site, infection period, and latent period of canker caused by Anisograma anomala in European filbert. Phytopathology, St. Paul, v. 70, n.11, p.1083-1087, 1980.

GRUPOPAULISTADEADUBAÇÃOECALAGEM PARA CITROS. Recomendações de adubação e calagem para citros no Estado de São Paulo. Laranja, Cordeirópolis, p.15, 1988.

GRUPOPAULISTADEADUBAÇÃOECALAGEM PARA CITROS. Recomendações de adubação e calagem para citros no Estado de São Paulo. Laranja, Cordeirópolis, p.27, 1994.

HARTMAN, J.R.; PARIS, L.; BAUTRAIS, P. Effect of leaf wetness duration, temperature, and conidial inoculum dose on apple scab infections. Plant Disease, St. Paul, v. 83, n.6, p. 531-534, 1999.
INMAN, A.J.; FITT, B.D.L.; TODD, A.D.; EVANS, R.L. Ascospores as primary inoculum for epidemics of white leaf spot (Mycosphaerella capsellae) in winter oilseed rape in the UK. Plant Patholology, Ottawa, v. 48, n.3, p.308-319, 1999.

JONES, R.M. Persistence of Arachis pintoi cv. Amarillo on three soil types of Samford, southeastern Queensland. Tropical Grasslands, Brisbane, v. 27, p.11-15,1993.

KIELY, T.B. Black spot of citrus. Agricultural Gazette, New South Wales, v. 1, p. 17-19, 1949.

KOTZÉ, J.M. Epidemiology and control of citrus black spot in South Africa. Plant Disease, St. Paul, v. 65, n.12, p.945-50, 1981.

MACHARDY, W.E.; GADOURY, D.M. Patterns of ascospores discharge by Venturia inaequalis. Phytopathology, St. Paul, v.76, n.10, p. 985-990, 1986.

McKINNEY, H.H. Influence of soil, temperature and moisture on infection of wheat seedlings by Helminthosporium sativum. Journal of Agricultural Research, Washington, v. 26, n.26, p.195-217, 1923.

McONIE, K.C. Source of inoculum of Guignardia citricarpa, the citrus black spot pathogen. Phytopathology, Beltsville, v.54, p.64-67, 1965.

McONIE, K.C. The latent occurrence in citrus and other hosts of a Guignardia easily confused with G. citricarpa, the citrus black spot pathogen. Phytopathology, Beltsville, v. 54, p.43, 1964.

PINKERTON, J.N.; JOHNSON, K.B.; STONE, J.K.; IVORS, K.L. Factors affecting the release of ascospores of Anisogramma anomala. Phytopathology, St. Paul, v.88, n.2, p.122-128, 1998.

PRATA, E.M.B.; ASSIS, M.A.; PINTO, S.A.F.; O mosaico florístico e estrutural de uma floresta ribeirinha em Rio Claro, SP. Revista Brasileira de Biociências, Porto Alegre, v. 5, Supl.2, p.984-986, 2007.

RABBINGE, R.; WARD, S.A.; VAN LAAR, H.H. Simulation and systems management in crop protection. Wageningen: PUDOC, 1989. p.420. 
REIS, R.F.; TIMMER, L.W.; GOES, A. de Effect of temperature, leaf wetness, and rainfall on the production of Guignardia citricarpa ascospores and on black spot severity on sweet orange. Fitopatologia Brasileira, Brasília, v. 31, n.1, p.29-34, 2006.

SCALOPPI, ELIANA MAYRA TORRECILLAS ET AL. Efeito do manejo cultural e químico na incidência e severidade da mancha-preta dos citros. Rev. Bras. Frutic, Mar 2012,vol.34,n. 1, p.102-108.

SOUSA, PATRÍCIA FERREIRA CUNHA; GOES, ANTONIO DE., Reação de laranjeiras-doces quanto à resistência a Guignardia citricarpa. Rev. Bras. Frutic., Set 2010, vol .32, n.3.

SPÓSITO, M.B., AMORIM, L.; BELASQUE JUNIOR, J. BASSANEZI, R.B.; AQUINO, R. Elaboração e validação de escala diagramática para avaliação da severidade da mancha preta em frutos cítricos. Fitopatologia Brasileira, Brasília, v. 29, n. 1, p.81-85, 2004.
STENSVAND, A.; GADOURY, D.M.;AMUNDSEN, T.; SEMB, L.; SEEM, R.C. Ascospores release and infection of apple leaves by conidia and ascospores of Venturia inaequalis at low temperatures. Phytopathology, St. Paul, v. 87, n.10, p.10461053, 1997.

SUTTON, B.C.; WATERSTON, J.M. Guignardia citricarpa descriptions of pathogenic fungi and bacteria. Surrey: Commonwealth mycological Institute, 1966.

VITTI, G.C. Amostragem e interpretação de análise de solo e de folha na citricultura. Jaboticabal: Funep, 1988. 32 p. 